\title{
Gender-Dependent Quality of Shade Matching of Dental Professionals and Students
}

\section{Sposobnost procjene boje stručnjaka iz različitih stomatoloških profesionalnih skupina i studenata dentalne medicine ovisno $o$ spolu}

\author{
${ }_{1}^{1}$ Private dental practice, Zagreb, Croatia \\ Privatna stomatološka ordinacija, Zagreb, Hrvatska \\ 2 Dental polyclinic Ars Salutaris, Zagreb, Croatia \\ Stomatološka poliklinika Ars salutaris, Zagreb, Hrvatska \\ ${ }^{3}$ Department of Removable Prosthodontics, School of Dental Medicine, University of Zagreb, Croatia \\ Zavod za mobilnu protetiku Stomatološkog fakulteta Sveučilišta u Zagrebu, Hrvatska
}

\section{Abstract}

Objectives: The purpose of this study was to evaluate shade matching ability of dental professionals and students using the VITA 3D-Master shade guide. Materials and methods: A hundred and twenty participants have been assigned to one of four groups as follows: specialists in prosthodontics (SPs), residents in prosthodontics (RPs), dental technicians (DTs) and dental students (DSs). The Tooth guide Training Box (TTB) was used to test the participants' shade-matching ability based on using 3 exercises and a final test. The mistakes were recorded during the exercises and mistake ratios (MR) were calculated. Time, scores, and color difference values $(\Delta \mathrm{E})$ were recorded and calculated. The one-way ANOVA was used to analyze the differences, and multiple regression analyses were used to evaluate the relationship in mean MRs, time, score and $\Delta E$ values between the groups. Results: Male participants needed significantly greater amount of time than females to complete the final test $(P<0.05)$. Male SPs achieved a significantly lower percentage of mistake ratios in second exercise than RPs $(P<0.05)$, needed significantly less time than DSs to complete the final test and achieved significantly higher scores than RPs $(P<0.05)$. Female SPs assessed the highest and DSs and RPs the lowest color differences $(P<0.05)$. The results obtained from the exercises and final tests highly affected the amount of estimated color difference in both male and female groups (by $78 \%$ and $76 \%$, respectively). Conclusions: Within the population tested, gender of the participants showed a significant impact on quality of shade matching of dental professionals and students.
Received: May 3, 2020

Accepted: September 21, 2020

Address for correspondence

Professor Ćelić Robert, PhD University of Zagreb

School of Dental Medicine

Department of Removable

Prosthodontics

Gundulićeva 5, 10000 Zagreb, Croatia

Tel: +38514802111

celic@sfzg.hr

Key words

Tooth Color; Color Shade; Artificial Teeth; Color Perception; Shade Guide

\section{Introduction}

An accurate color of restoration is of a great importance to patients' satisfaction with esthetic dental outcome. Therefore, the shade determination is an important procedure in everyday dental practice, not only when using ceramic material, but also when using composite resins.

The visual analysis of natural tooth in comparison with shade guide is the fastest and least expensive method, most frequently used in dentistry (1). But color evaluation by visual comparison is a subjective method which is difficult to perform because of different environmental influences, a viewer's interpretation and tools used (2-7).

The research carried out by Paravina et al. proved that VITA Classical A1-D4 and VITA 3D-Master shadeguides are the most frequently used shade guides (8). When it comes to teaching methods, a survey of European dental students pub-

\section{Uvod}

Točna boja protetičkoga rada znatno utječe na pacijentovo zadovoljstvo estetskim ishodom terapije. Prema tome, procjena boje važan je postupak u svakodnevnoj kliničkoj praksi, ne samo pri uporabi keramičkih materijala nego i kompozita. Vizualna analiza prirodnih zuba uporabom ključa boja najbrža je i najjeftinija metoda i najčešće je korištena u stomatologiji (1). No određivanje boje vizualnom usporedbom subjektivna je metoda i teže se obavlja zbog različitih utjecaja iz okolice, procjeniteljeve interpretacije i korištenih alata $(2-7)$.

Istraživanje koje su proveli Paravina i suradnici dokazalo je da se liječnici dentalne medicine najčešće koriste ključevima VITA Classical A1-D4 i VITA 3D-Master (8). Kada se govori o metodama učenja, istraživanje europskih studenata dentalne medicine objavljeno 2011. godine pokazalo je 
lished in 2011 showed that for educational purposes the most commonly used is VITA Classical A1-D4 shade guide (1767\%), followed by the VITA 3D-Master (0-47\%)(9).

On the other hand, despite its widespread use, the VITA Classical A1-D4 shade guide demonstrated some difficulties with the shades that were not grouped systematically, and with the development of the 3D-Master shade guide a more systematic approach toward shade matching, with color distribution performed according to Munsell's principles, was introduced in dentistry $(10,11)$.

In order to assess tooth color using the 3D Master shade guide as precise as possible and practice the procedure, the system known as the Toothguide Training Box (TTB) Mark II (Vita Zahnfabrik, Bad Sackingen, Germany) was developed to help dentists with tooth shade selection (12-14). It allows a dentist to systematically select tooth shades by determining color appearances in accordance with natural tooth color observation under the standardized artificial daylight and color temperature of $5500 \mathrm{~K}(15,16)$.

The purpose of this study was to evaluate and compare the shade matching ability of four different dental occupational groups - dental technicians (DTs), residents in prosthodontics (RPs), specialists in prosthodontics (SPs) and dental students (DSs) using the VITA 3D-Master shade guide.

The first null hypothesis was that there were no gender differences in the results obtained from the exercises and the final tests using TTB in four different groups, depending on the level of their clinical experience in tooth shade evaluation. The second null hypothesis was that there were no differences in the results obtained from the exercises and final tests between four examined groups in each gender group. The third null hypothesis was that no impact of the results obtained from the exercises and final tests on the amount of estimated color difference in both gender groups was demonstrated.

\section{Material and methods}

The project of this study was approved by the Ethics Committee of the School of Dental Medicine, University of Zagreb, Croatia.

\section{Sample size and exclusion criteria}

The sample consisted of 120 participants, 30 in each of four investigated groups - DTs, RPs, SPs and DSs. A total sample size and distribution, as well as exclusion criteria and the number of participants excluded from the study have already been described in our previous paper (17).

\section{TTB}

For the study, the TTB was used. The data concerning the protocol of the TTB use has also been described in our previous paper (17).

The participants in this study had to undergo the following three structured exercises: selecting lightness, chroma and hue, respectively. After that they had to undertake the final test in which they assessed lightness, chroma and hue for each of 15 tested teeth. da se u edukacijske svrhe najčěše odabire ključ za boju VITA Classical A1-D4 (17 - $67 \%)$, a zatim VITA 3D-Master $(0-47 \%)(9)$.

Istaknimo da, unatoč širokoj upotrebi, ključ za boju VITA Classical A1-D4 pokazuje određene poteškoće s primjercima boja koje nisu sustavno grupirane. Tek razvojem ključa za boju 3D-Master postiže se sustavni pristup procjeni boje $s$ raspodjelom boje prema Munsellovim načelima u stomato$\operatorname{logiji}(10,11)$.

Kako bi procjena boje zuba upotrebom ključa za boju 3D-Master bila što preciznija, razvijen je sustav Toothguide Training Box (TTB) Mark II (Vita Zahnfabrik, Bad Sackingen, Njemačka) koji doktorima dentalne medicine pomaže u uvježbavanju postupka $(12-14)$. Sustav omogućuje liječniku da sistematski odabere boju zuba određivanjem izgleda boje u skladu s promatranjem prirodne boje zuba pod standardiziranim dnevnim svjetlom i temperaturom boje od $5500 \mathrm{~K}(15,16)$.

Cilj ove studije bio je ispitati i usporediti sposobnost procjene boje četiriju različitih stomatoloških profesionalnih skupina - zubnih tehničara (DT), specijalizanata stomatološke protetike (RP), specijalista stomatološke protetike (SP) i studenata dentalne medicine (DS) korištenjem ključa za boju 3D-Master.

Prva nulta hipoteza bila je da ne postoje spolne razlike u rezultatima dobivenima tijekom vježbi i u završnom testu na TTB uređaju u četirima različitim skupinama, ovisno o razini njihova kliničkog iskustva u procjeni boje zuba. Druga nulta hipoteza glasila je da nema razlike u rezultatima dobivenima tijekom vježbi i u završnim testovima između četiriju ispitivanih skupina u svakoj skupini spola. Treća nulta hipoteza bila je da nema utjecaja rezultata dobivenih u vježbama i završnim testovima na iznos procijenjene razlike u boji u objema spolnim skupinama.

\section{Materijal i postupci}

Projekt ove studije odobrilo je Etičko povjerenstvo Stomatološkog fakulteta Sveučilišta u Zagrebu, Hrvatska.

\section{Veličina uzorka i kriteriji za isključivanje iz istraživanja}

Uzorak se sastojao od 120 ispitanika, po 30 u svakoj od četiriju ispitivanih skupina - DT-i, RP-i, SP-i i DS-i. Ukupni uzorak i raspodjela, zatim kriteriji za isključivanje te broj ispitanika isključenih iz studije, već su objašnjeni u našem prethodnom članku (17).

\section{TTB}

U ovoj je studiji korišten TTB uređaj. Svi podatci o protokolu upotrebe TTB uređaja također su bili objašnjeni u našem članku (17).

Ispitivači u ovoj studiji bili su podvrgnuti trima strukturiranim vježbama u kojima su procjenjivali svjetlinu, zasićenost i nijansu boje. Nakon toga su u završnom testu procjenjivali svjetlinu, zasićenost i nijansu boje za svaki od 15 testiranih zuba. 


\section{Mistake ratio (MR)}

The number of true answers from all three exercises of each participant was collected and the accuracy expressed as the mistake ratio of correct and total number of tries (MR 1, MR 2, and MR 3).

\section{Time $(\mathrm{t} / \mathrm{s})$}

The time required to finish the final test was recorded in seconds in all four examined study groups.

\section{Score}

At the end of the final test each participant received a score with maximum of 1000 points.

\section{Mean $\Delta \mathrm{E}$}

The calculation of color difference between the task and selected colors has also been described in our previous paper (17). In calculation, the accurate answers were recorded as $\Delta \mathrm{E}=0$.

\section{Statistical analysis}

The received data were entered into Excel database. Subsequently, they were statistically evaluated and introduced into statistical program SPSS 19.0 (SPSS, Chicago, IL, USA).

The Student's $t$ test was used to compare gender differences in mean MR1, MR2, MR3, time, score and $\triangle \mathrm{E}$.

The one-way ANOVA was used in each gender group to determine whether there were any differences in mean MR1, $\mathrm{MR} 2, \mathrm{MR} 3$, time, score and $\Delta \mathrm{E}$ values between four different examined groups, and the Bonferroni corrected post hoc tests (paired t-tests) were used to explore the differences within the groups. The differences were considered statistically significant with $\mathrm{P}<0.05$.

Multiple regression analyses were used to evaluate the relationship of mean MR1, MR2, MR3, the time and score and mean $\Delta \mathrm{E}$ values in both gender groups.

\section{Results}

126 subjects participated in our study, but only 120 were included in the study (95\%). Six participants were excluded because they had previous knowledge and shade selection experience with 3D Master shade guide (2 RPs and 4 SPs), and the evaluation of the Ishihara test did not reveal color vision deficiency in any participants.

All measured variables in this study were tested for differences by gender. The results revealed significantly higher values for time needed to complete the final test in men than in women, and therefore the data in further statistical analysis were split by gender $(\mathrm{t}=2.2 ; \mathrm{df}=118 ; P=0.03)$ (Figure 1).

The mistake ratios (MR) of four occupational groups by gender are shown in Figure 2. Male SPs achieved a significantly lower percentage of mistake ratios in second exercise (MP2) than $\mathrm{RPs}(\mathrm{F}=4.0$; $\mathrm{df}=3 ; P=0.01)$. With regard to the final test scores, male SPs needed significantly less time than DSs to complete the final test $(\mathrm{F}=3.8 ; \mathrm{df}=3 ; P=0.02)$ and achieved significantly higher scores than $\mathrm{RPs}(\mathrm{F}=2.9$; $\mathrm{df}=3$; $P=0.04$ ) (Figures 1 and 3). In women, the SPs group assessed

\section{Omjer pogreške (OP)}

Za svakog ispitanika zabilježen je broj točnih odgovora iz svih triju vježbi te je točnost prikazana kao omjer pogreške točnih i ukupnog broja pokušaja (OP1, OP2, OP3).

\section{Vrijeme $(\mathrm{t} / \mathrm{s})$}

Vrijeme potrebno da se obavi završni test bilježilo se u sekundama u svim četirima ispitivanim skupinama istraživanja.

\section{Rezultati}

$\mathrm{Na}$ kraju završnog testa svakog ispitanika dobiven je rezultat koji je mogao dosegnuti najviše 1000 bodova.

\section{Srednja $\Delta$ E vrijednost}

Izračun razlike u boji između ponuđenih i odabranih boja bio je također opisan u našem ranijem radu (17). U izračunu su se točni odgovori bilježili kao $\Delta \mathrm{E}=0$.

\section{Statistička analiza}

Dobiveni rezultati unosili su se u Excelovu bazu podata$\mathrm{ka}$, statistički procijenili i unijeli u statistički program SPSS 19.0 (SPSS, Chicago, IL, SAD).

Studentovim t-testom koristili smo se za usporedbu srednjih vrijednosti OP1, OP2, OP3, vremena, rezultata i $\Delta \mathrm{E}$ vrijednosti prema spolu.

Jednosmjerni ANOVA test primijenjen je za određivanje razlike u srednjim vrijednostima OP1, OP2, OP3, vremenu, rezultatu i $\Delta \mathrm{E}$ vrijednostima između četiriju ispitivanih skupina u muškoj i u ženskoj skupini ispitanika. Bonferronijevi korigirani post hoc testovi (t-testovi za zavisne uzorke) upotrijebljeni su kako bi se dokazala razlika unutar skupina. Razlike su smatrane statistički značajnima na razini $\mathrm{p}<0,05$.

Multipla regresijska analiza korištena je za procjenu odnosa srednjih vrijednosti OP1, OP2, OP3, vremena, rezultata na $\Delta \mathrm{E}$ vrijednosti kod muških i ženskih ispitanika.

\section{Rezultati}

U ovom istraživanju ukupno je sudjelovalo 126 ispitanika, a njih 120 na kraju je bilo uključeno u studiju (95\%). Šest ispitanika isključeno je jer su izjavili da poznaju sustav $i$ imaju određeno iskustvo u procjeni boje s pomoću ključa 3D Master (2 RP-a i 4 SP-a). Ishiharin test nije otkrio odstupanja u procjeni boja ni kod jednog ispitanika.

Sve mjerene varijable u ovom istraživanju bile su testirane prema spolu. Rezultati su pokazali da je ispitanicima trebalo znatno više vremena da dovrše završni test od ispitanica te se zato odlučilo u daljnjoj analizi podijeliti skupine prema spolu $(\mathrm{t}=2,2 ; \mathrm{df}=118 ; P=0,03)$ (slika 1.).

Omjeri pogrešaka (OP) četiriju stomatoloških profesionalnih skupina prema spolu prikazani su na slici 2. Muški SP-i postigli su značajno niži postotak omjera pogrešaka u drugoj vježbi $(\mathrm{OP} 2)$ negoli $\mathrm{RP}-\mathrm{i}(\mathrm{F}=4,0 ; \mathrm{df}=3 ; P=0,01)$. $S$ obzirom na rezultate završnoga testa, muškim SP-ima bilo je potrebno znatno manje vremena negoli DS-ima da dovrše završni test $(\mathrm{F}=3,8 ; \mathrm{df}=3 ; P=0,02)$, a postigli su značajno bolje rezultate negoli $\mathrm{RP}-\mathrm{i}(\mathrm{F}=2,9 ; \mathrm{df}=3 ; P=0,04)($ sli- 

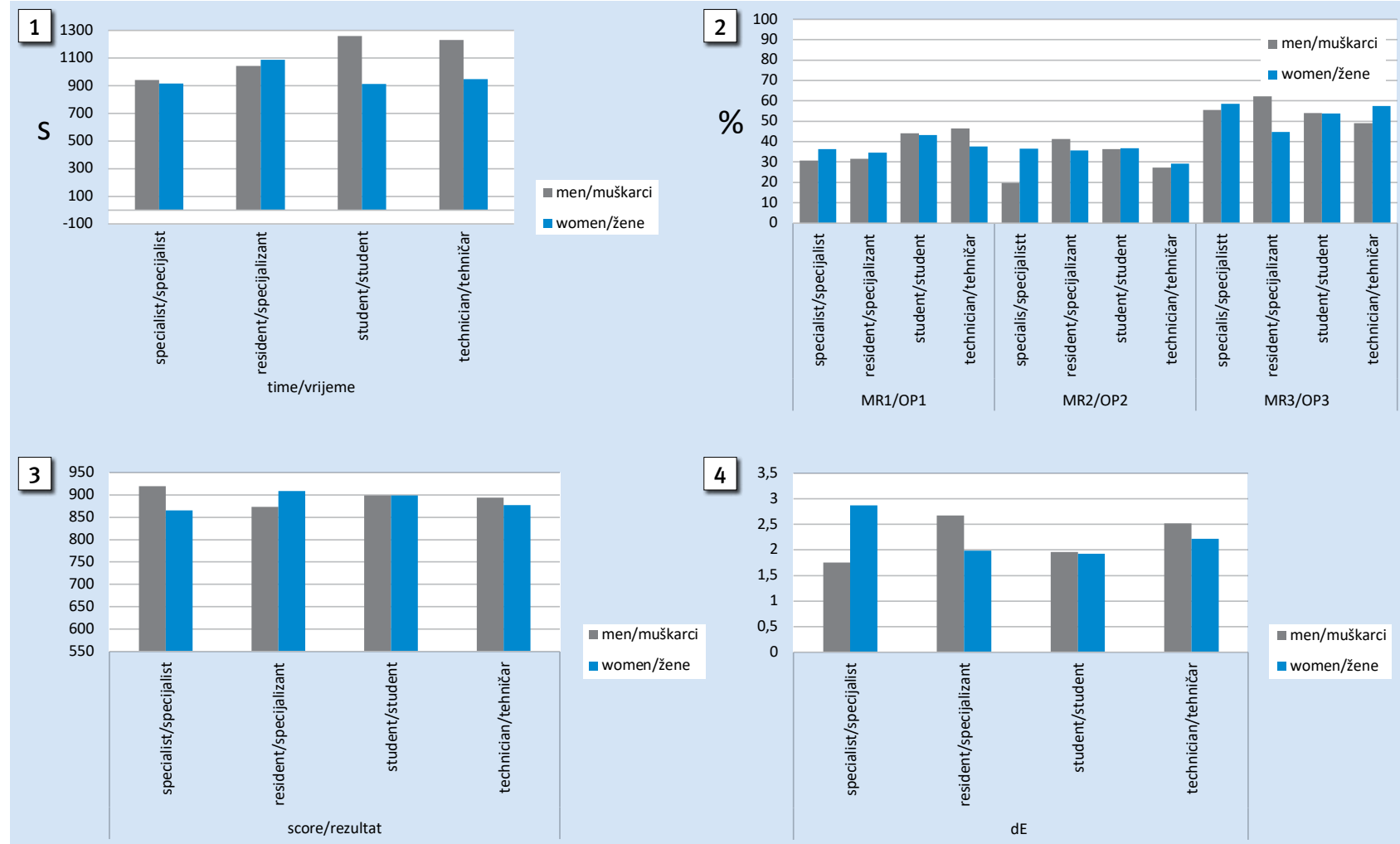

Figure 1 Values for time in seconds (s) needed to complete the final test of four occupational groups by gender.

Slika 1. Vrijednosti vremena u sekundama (s) potrebnog za dovršetak završnog testa u četirima ispitanim skupinama prema spolu Figure 2 The mistake ratios (MR - \%) of four occupational groups by gender.

Slika 2. Omjeri pogreške (OP - \%) u četirima ispitanim skupinama prema spolu

Figure 3 The final test scores of four occupational groups by gender.

Slika 3. Rezultati završnog testa u četirima ispitanim skupinama prema spolu

Figure 4 Calculated color differences $(\Delta \mathrm{E})$ of four occupational groups by gender.

Slika 4. Izračunata razlika u boji $(\Delta \mathrm{E}) \mathrm{u}$ četirima ispitanim skupinama prema spolu

Table 1 Multiple regression analysis of the association between results obtained from three exercises and final tests and color differences $(\Delta \mathrm{E})$ in two gender groups

Tablica 1. Multipla regresijska analiza utjecaja rezultata triju vježbi i završnih testova na razliku u boji $(\Delta \mathrm{E}) \mathrm{u}$ muških i ženskih ispitanika

\begin{tabular}{|c|c|c|c|c|c|c|c|c|}
\hline & \multicolumn{2}{|c|}{$\mathbf{R}$} & \multicolumn{2}{|c|}{$\mathbf{R}^{2}$} & \multicolumn{2}{|c|}{$\mathbf{P}$} & \multicolumn{2}{|c|}{ SE } \\
\hline & $\begin{array}{c}\text { Men • } \\
\text { Muškarci }\end{array}$ & $\begin{array}{l}\text { Women • } \\
\text { Žene }\end{array}$ & $\begin{array}{c}\text { Men • } \\
\text { Muškarci }\end{array}$ & $\begin{array}{l}\text { Women • } \\
\text { Žene }\end{array}$ & $\begin{array}{c}\text { Men • } \\
\text { Muškarci }\end{array}$ & $\begin{array}{l}\text { Women • } \\
\text { Žene }\end{array}$ & $\begin{array}{c}\text { Men` } \\
\text { Muškarci }\end{array}$ & $\begin{array}{c}\text { Women • } \\
\text { Žene }\end{array}$ \\
\hline$\Delta \mathrm{E}$ & 0.89 & 0.90 & 0.78 & 0.80 & $>0.05$ & $>0.05$ & 0.49 & 0.43 \\
\hline
\end{tabular}

$\mathrm{R}$ - correlation coefficient $\bullet$ koeficijent korelacije; $\mathrm{R}^{2}$ - coefficient of determination $\bullet$ koeficijent determinacije; $\mathrm{P}$ - significance $\bullet$ značajnost;

$\mathrm{SE}$ - standard error $\bullet$ standardna pogreška

the highest and DSs and RPs the lowest color differences $(\Delta \mathrm{E})(\mathrm{F}=3.5 ; \mathrm{df}=3 ; P<0.02)$ (Figure 4).

In a multiple regression analysis, the combination of the results obtained from three exercises and final tests in men explained the variability of $\Delta \mathrm{E}$ by $78 \%(P>0.05)$ (Table 1$)$. In women, the combination of the same independent variables explained the variability of $\Delta \mathrm{E}$ by $80 \%(P>0.05)$ (Table 1$)$.

\section{Discussion}

The purpose of this study was to evaluate and compare the shade matching ability of four different dental occupational groups - dental technicians (DTs), residents in prosthodontics (RPs), specialists in prosthodontics (SPs) ke 1. i 3.). U ženskoj skupini SP-a procijenjena razlika u boji bila je najviša, a kod DS-a i $\mathrm{RP}$-a najniža $(\Delta \mathrm{E})(\mathrm{F}=3,5 ; \mathrm{df}=$ 3; $P<0,02)$ (slika 4.).

U multiploj regresijskoj analizi kombinacija rezultata dobivenih iz triju vježbi i završnih testova kod muškaraca je utjecala na varijabilnost $\Delta \mathrm{E} 78 \%(P>0,05)$ (tablica 1.). Kod žena je kombinacija istih nezavisnih varijabli utjecala $80 \%$ na varijabilnost $\Delta \mathrm{E}-\mathrm{a}(P>0,05)$ (tablica 1 .).

\section{Rasprava}

Svrha ovog istraživanja bila je ispitati i usporediti sposobnost procjene boje stručnjaka iz četiriju različitih stomatoloških profesionalnih skupina - dentalnih tehničara (DT), specijalizanata stomatološke protetike (RP), specijalista sto- 
and dental students (DSs) using the VITA 3D-Master shade guide.

The first null hypothesis that there will be no gender differences in the results obtained from the exercises and the final test using TTB in four examined groups, depending on their level of clinical experience in tooth shade assessment was rejected. The results of our study showed a statistically significant difference in time needed to finish the final test by gender $(\mathrm{t}=2.2 ; \mathrm{df}=118 ; P=0.03)$ (Figure 1$)$. It seemed that men needed more time than women, 17.4 minutes, and 16.1 minutes, respectively. These results are in accordance with Pohlen et al. study where they found gender to play an important role in shade matching, with female groups of participants to select lightness and chroma better compared to their male counterparts (18).

In male group in this study, SPs were the fastest in color matching and achieved lowest mistake ratios in second exercise and male DSs were the slowest in color matching with highest mistake ratios in the same exercise $(P<0.05)$. At the same time, male SPs achieved highest scores and male RPs the lowest in the final test $(P<0.05)$. Ortolan et al. obtained the same results, with clinicians performing the shade tab matching faster than students (19). The reason for that may lie in the fact that the specialists in prosthodontics assess the color of the teeth using different shadeguides on their everyday basis compared to the students who are less experienced in this field.

According to the abovementioned results, the second null hypothesis that there will be no differences in the results obtained from the exercises and final tests between four examined groups in each gender group was also rejected. In this study, the participants were asked to undergo three exercises where they had to correctly select lightness, lightness and chroma together and, subsequently, lightness, chroma and hue of the tested teeth together, respectively. After that, the participants had to undertake the final test assessing all abovementioned color characteristics for 15 tested teeth. Although a significant difference in MR2 was found between male SPs and RPs, MRs reached the highest values for both genders (around $50 \%$ of mistaken selections) in the third exercise where they were obliged to assess all three color parameters together (Figure 2). It seems that this protocol was found to be the most complicated.

The results of the research of Sinmazisik et al. showed that general dentists made a larger number of mistakes in lightness parameter, and dental technicians students in hue parameter of the color (20). In our study, male DTs made a larger number of mistakes in lightness parameter $(P>0.05)$, and male RPs made a larger number of mistakes in lightness and chroma and lightness, chroma and hue exercises $(P<0.05)$, while the female group was more uniform in assessment $(P>0.05$; Figure 2). In their study, Haddad et al. were unable to determine the influence of experience on shade matching. Conversely, Capa et al., as well as Ragain et al., found professional experience to be associated positively with the outcome of matching the shade (21-23).

With regard to the final test scores and $\Delta \mathrm{E}$ values in our study, no significant differences were found between occu- matološke protetike (SP) i studenata dentalne medicine (DS) uporabom ključa za boju VITA 3D-Master.

Prva nulta hipoteza, da ne postoji razlika u rezultatima muških i ženskih ispitanika dobivenima iz vježbi i završnoga testa, a upotrebom TTB uređaja u četirima ispitivanim skupinama ovisno o razini njihova kliničkog iskustva u procjeni boje zuba, bila je odbačena. Rezultati našeg istraživanja pokazali su da postoji statistički značajna razlika u vremenu potrebnom za dovršetak završnog testa prema spolu $(\mathrm{t}=2,2 ; \mathrm{df}$ $=118 ; P=0,03)$ (slika 1.). Čini se da je muškarcima bilo potrebno više vremena negoli ženama - 17,4 minute i $16,1 \mathrm{mi}$ nuta. Ti rezultati bili su u skladu sa studijom Pohlena i suradnika koji su dokazali da spol ima važnu ulogu u procjeni boje, odnosno njihovi rezultati pokazali su da ispitanice bolje određuju svjetlinu i zasićenost u usporedbi $s$ ispitanicima (18).

U muškoj skupini u ovom istraživanju SP-i su bili najbrži u procjeni boje i postigli su najniže omjere pogrešaka u drugoj vježbi, a muški DS-i bili su najsporiji u procjeni boje $s$ najvišim omjerima pogrešaka u istoj vježbi $(P<0,05)$. Istodobno su u završnom testu muški SP-i postigli najviše rezultate, a muški RP-i najniže $(P<0,05)$. Ortolan i suradnici dokazali su također da su kliničari brže procjenjivali boju od studenata dentalne medicine (19). Razlog za to može biti u činjenici da specijalisti stomatološke protetike procjenjuju boju zuba svaki dan koristeći se različitim ključevima boja u odnosu prema studentima dentalne medicine koji su neiskusniji u tom poslu.

U skladu s prije navedenim rezultatima, druga nulta hipoteza da nema razlike u rezultatima dobivenima iz vježbi i završnih testova između četiriju ispitivanih skupina u muškoj i ženskoj skupini ispitanika pojedinačno, bila je također odbačena. U ovom istraživanju od ispitanika se tražilo da obave tri vježbe kako bi ispravno odabrali svjetlinu, svjetlinu i zasićenost zajedno te svjetlinu, zasićenost i nijansu boje testiranih zuba također zajedno. Nakon toga ispitanici su proveli završni test kojim se procjenjuju sva tri navedena svojstva boje za 15 testiranih zuba. Premda je nađena značajna razlika u OP2 između muških SP-a i RP-a, omjeri pogrešaka $(\mathrm{OP})$ za oba spola dosegnuli su najviše vrijednosti (oko $50 \%$ pogrešnih odabira) u trećoj vježbi u kojoj je zadatak bio da se istodobno procjene sva tri parametra boje (slika 2). Može se zaključiti da se taj protokol pokazao najsloženijim.

Sinmazisik i suradnici dokazali su da doktori dentalne medicine čine više pogrešaka u parametru svjetline, a učenici dentalni tehničari u parametru nijanse boje (20). U našem istraživanju muški DT-i imali su više pogrešaka pri procjeni svjetline $(P>0,05)$, muški RP-i pri procjeni svjetline i zasićenosti, te svjetline, zasićenosti i nijanse $(P<0,05)$, a ženska skupina bila je ujednačenija u procjeni $(P>0,05$; slika 2.). U svojem istraživanju Haddad i suradnici nisu bili u mogućnosti odrediti utjecaj iskustva u procjeni boje, no Capa i suradnici te Ragain i suradnici dokazali su da je stručno iskustvo pozitivno utjecalo na ishod određivanja boje $(21-23)$.

$S$ obzirom na rezultate završnog testa i $\Delta E$ vrijednosti, u našem istraživanju nisu pronađene značajne razlike između stručnih profesionalnih skupina u muškaraca, SP i DS skupine postigle su više rezultate (919 i 899) i niže $\Delta \mathrm{E}$ vrijednosti $(1,75$ i 1,95) od RP-a i DT-a (873 i 893, 2,67 i 2,52) 
pational groups in men, and SPs and DSs groups obtained higher scores (919 and 899) and lower $\Delta \mathrm{E}$ values (1.75 and 1.95) than RSs and DTs (873 and 893, 2.67 and 2.52, respectfully) ( $\mathrm{P}>0.05$; Figures 3 and 4). This result is in accordance with the results of the research conducted by Sinmazisik et al (20).

At the same time, however, the results were completely different in the female group in our study. The SPs obtained the lowest scores and the highest $\Delta \mathrm{E}$ values and the RPs vice versa, and this difference was found to be significant $(\mathrm{F}=3.5$; $\mathrm{df}=3 ; \mathrm{P}=0.02$ ) (Figures 3 and 4 ). This result was surprising, but if we look at the rest of the results and compare these female occupational groups, we will see that female SPs needed less time (15.2 $\mathrm{min})$ to accomplish the entire task than female RPs (18.1 min), and they made a larger number of mistakes in the third exercise when matching lightness, chroma and hue together, which turned out to be the most difficult task (Figures 1-4). It seems that two minutes longer assessment was the most crucial for female occupational groups.

The third null hypothesis was that no impact of the results obtained from the exercises and final tests on the amount of estimated color difference in both gender groups will be demonstrated. But this was rejected because the results of multiple regression analysis revealed that there was a great impact of the variables observed in this study on the variability of $\triangle \mathrm{E}$. In men, it amounted to $78 \%$, and in women $80 \%$ (P>0.05) (Table 1). It needs to be emphasized that the respondents who have previously contributed to comparable research or have been practicing color assessment, or those who had some previous shade selection knowledge or training on using the 3D Master shade guide, were excluded from the study. Therefore, the participants included in this study were dental occupational staff who accomplished this type of task for the first time with no preliminary lectures. They have undergone three training exercises where they have learnt how to assess color arranged by lightness, chroma and hue, step-by-step, and, after that, they did their final test. The results of our study proved that this type of training with no previous lectures strongly influenced the final result in both male and female groups $(\Delta \mathrm{E})(P>0.05)$ (Table 1). Many experts in this field have already emphasized the need for training in color science and found that lessons on color selection, along with training and experience can improve the color matching ability of dental professionals (14, 20-24). At the same time, various articles claim that previous experience does not improve nor has a minimal impact on the ability of color selection $(18,21,25)$.

In this study, we wanted to investigate not only the results of the final test, but also the results of three exercises preceding the final test in order to explore their impact on the amount of estimated color difference. In our further study, we want to explore in detail which VITA 3D-Master shades were most often assessed accurately. Additionally, we would like to investigate into the VITA 3D-Master shades that were most often assessed incorrectly in different dental occupational groups.
(P > 0,05; slike 3. i 4.). Taj rezultat poklapa se s rezultatima istraživanja Sinmazisika i suradnika (20).

No istodobno su u ženskoj skupini u našem istraživanju rezultati bili potpuno različiti. Specijalistice protetike postigle su najniže rezultate i najviše vrijednosti u razlikama boje, a specijalizantice protetike obrnuto, te je ova razlika bila značajna ( $\mathrm{F}=3,5 ; \mathrm{df}=3 ; \mathrm{P}=0,02$, (slike 3. i 4.). Taj rezultat iznenađuje, ali ako pogledamo ostatak rezultata i usporedimo ove ženske profesionalne skupine, vidjet ćemo da su istodobno ženski SP-i potrošili manje vremena (15,2 minute) da završe cijeli zadatak u odnosu prema ženskim RP-ima (18,1 minuta) te su učinili više pogrešaka u trećoj vježbi pri određivanju svjetline, zasićenosti i nijanse zajedno, što se ispostavilo kao najveća poteškoća (slike 1. - 4.). Čini se da je dvije minute dulja procjena boje bila najznačajnija u ženskim profesionalnim skupinama.

Treća nulta hipoteza bila je da nema utjecaja rezultata dobivenih iz vježbi i završnih testova na iznos procijenjene razlike u boji u objema skupinama prema spolu. Ipak ta je hipoteza bila odbačena jer su rezultati multiple regresijske analize pokazali velik utjecaj ispitivanih varijabli u ovom istraživanju na varijabilnost $\Delta \mathrm{E}$. Kod muškaraca oni objašnjavaju to u 78 $\%$ slučajeva, a kod žena u $80 \%(P>0,05)$ (tablica 1 .). Treba istaknuti da su ispitanici koji su prije sudjelovali u sličnom istraživanju, ili su već vježbali određivanje boje te posjeduju određeno znanje u procjeni boje i vježbali su $s$ ključem boja 3D Master, bili isključeni iz istraživanja. Prema tome ispitanici su bili profesionalni djelatnici koji su ovaj zadatak s ključem 3D Master za boju proveli prvi put i to bez uputa. Sudjelovali su samo u trima vježbama na kojima su, korak po korak, naučili kako odrediti boju sastavljenu od svjetline, zasićenosti i nijanse, nakon čega je slijedio završni test. Rezultati našeg istraživanja dokazali su da ta vrsta uvježbavanja procjene boje bez ranijih uputa snažno utječe na završni rezultat i u skupini muških i ženskih ispitanika $(\Delta \mathrm{E})(P>0,05)$ (tablica 1.). Mnogi stručnjaci u ovom području neprestance ističu potrebu za uvježbavanjem procjene boje i dokazali su da učenje, uvježbavanje i iskustvo mogu poboljšati sposobnost određivanja boje kad je riječ o stomatološkim profesionalcima (14, 20 - 24). Istodobno autori različitih članaka tvrde da ranije iskustvo ne poboljšava sposobnost odabira boje, ili samo minimalno utječe na to $(18,21,25)$.

U ovom istraživanju željeli smo analizirati ne samo rezultate završnoga testa, nego smo uključili rezultate triju uvodnih vježbi koje su prethodile završnom testu sa svrhom ispitivanja njihova utjecaja na iznos procijenjene razlike u boji. U daljnjem istraživanju želimo detaljno ispitati koje su VITA 3D-Master boje u različitim stomatološkim profesionalnim skupinama najčešće određene točno, odnosno netočno. 


\section{Conclusions}

In this study, men needed more time to complete the final test. Male SPs made a smaller number of mistakes in second exercise, needed significantly less time to complete the final test and achieved significantly higher scores $(P<0.05)$. Female SPs assessed highest, and DSs and RPs the lowest color differences $(P<0.05)$. When assessing lightness, chroma and hue simultaneously, the participants made a larger number of mistakes. Male SPs and DTs were the most successful in final shade matching, and female DSs were more successful than female SPs. The results of exercises and final tests influenced the amount of color difference in both men and women.

\section{Conflict of interest}

\author{
None declared
}

\section{Contribution to the paper:}

Ž.D. - writing the article (Introduction/Purpose of the study, Material and methods; Results, Discussion with Conclusions); sample collection (dental students, dental prosthetics specialists, dental technicians); implementation of the experimental part of the study, review of the scientific literature; H.P. - sample collection (dental technicians; dental prosthetics specialists); R.Ć. - writing the article (Introduction/Purpose of the study, Material and methods; Results, Discussion with Conclusions - control of the whole writing process), sample collection (dental students, dental prosthetics specialists, dental prosthetic specialists, dental technicians); review of the scientific literature.

\section{Zaključci}

Muškarci su u ovom istraživanju potrošili više vremena da dovrše završni test. Specijalisti stomatološke protetike (SP) imali su manje pogrešaka u drugoj vježbi, trebalo im je znatno manje vremena da dovrše završni test i postigli su značajno bolje rezultate $(P<0,05)$. Specijalistice protetike $(S P)$ imale su najviše, a dentalne studentice (DS) i specijalizantice stomatološke protetike (RP) najniže razlike u boji $(P<$ $0,05)$. Kada se procjenjivala svjetlina, zasićenost i nijanse boje istodobno, ispitanici su učinili više pogrešaka. Specijalisti (SP) i dentalni tehničari (DT) bili su najuspješniji u završnoj procjeni boje, a studentice dentalne medicine (DS) bile su uspješnije od specijalistica stomatološke protetike (SP). Rezultati vježbi i završnih testova utjecali su na iznos razlike u boji muških i ženskih ispitanika.

\section{Sukob interesa}

Nije bilo sukoba interesa.

\section{Doprinos autora}

Ž. U. - pisanje članka (Uvod/Svrha istraživanja, Materijal i metoda; Rezultati, Rasprava s zaključcima); skupljanje uzorka (studenti dentalne medicine, specijalizanti stomatološke protetike, zubni tehničari); provedba eksperimentalnog dijela istraživanja, pregled znanstvene literature; H. P. - skupljanje uzorka (zubni tehničari, specijalisti stomatološke protetike); R. Ć. - pisanje članka (Uvod/Svrha istraživanja, Materijal i metoda; Rezultati, Rasprava s zaključcima - kontrola cijelog procesa pisanja), skupljanje uzorka (studenti dentalne medicine, specijalizanti stomatološke protetike, specijalisti stomatološke protetike, zubni tehničari); pregled znanstvene literature.

\section{Sažetak}

Svrha istraživanja: Cilj ovog istraživanja bio je ispitati sposobnost procjene boje stomatoloških profesionalaca i studenata dentalne medicine uporabom ključa za boje Vita 3D. Materijal i postupci: Stotinu i dvadeset ispitanika raspodijeljeno je u jednu od četiriju skupina: za specijaliste stomatološke protetike (SP), specijalizante stomatološke protetike (RP), dentalne tehničare (DT) i studente dentalne medicine (DS). Korišten je Toothguide Training Box (TTB) za testiranje sposobnosti procjene boje ispitivača koji se sastojao od triju vježbi i završnog testa. Pogreške su bile zabilježene. Tijekom vježbi svakom je ispitaniku zabilježen broj pogrešaka na temelju kojih su izračunati omjeri pogreške (OP). Također su zabilježeni vrijeme i rezultati završnog testa te je izračunata vrijednost razlika boje $(\Delta E)$. Pri analizi razlika korišten je jednosmjerni test ANOVA, a za procjenu utjecaja prosječnih OP-a, vremena i rezultata na vrijednosti $\Delta \mathrm{E}$ među skupinama multipla regresijska analiza. Rezultati: Ispitanici su potrošili znatno više vremena za završni test od ispitanica $(P<0,05)$. Muški SP-i ostvarili su značajno niži postotak omjera pogreške u drugoj vježbi u usporedbi s RP-ima $(P<0,05)$ i trebali su znatno manje vremena nego DS-i da obave završni test te postignu značajno više rezultate od RP-a $(P<$ 0,05). Ženski SP-i pri određivanju boje postigli su najviše, a DS-i i RP-i najniže razlike u boji $(P<0,05)$. Rezultati dobiveni iz vježbi i završnih testova izrazito su utjecali na iznos procijenjene razlike boje $u$ objema muškim i ženskim skupinama (78 \% i 80 \%). Zaključci: Unutar testirane populacije spol ispitanika pokazao je značajan utjecaj na kvalitetu procjene boje stomatoloških profesionalaca i studenata dentalne medicine.
Zaprimljen: 3. svibnja 2020.

Prihvaćen: 21. rujna 2020.

Adresa za dopisivanje

Robert Ćelić

Sveučilište u Zagrebu, Stomatološki

fakultet

Zavod za mobilnu protetiku

Gundulićeva 5, 10000 Zagreb,

Hrvatska

celic@sfzg.hr

Ključne riječi

boja zuba; nijanse boja; umjetni zub; opažanje boja

\section{References}

1. Van der Burgt TP, ten Bosch JJ, Borsboom PC, Kortsmit WJ. A comparison of new and conventional methods for quantification of tooth color. J Prosthet Dent. 1990 Feb;63(2):155-62.

2. Chu SJ, Trushkowsky RD, Paravina RD. Dental color matching instruments and systems. Review of clinical and research aspects. J Dent. 2010;38 Suppl 2:e2-16.
3. Paul SJ, Peter A, Rodoni L, Pietrobon N. Conventional visual vs spectrophotometric shade taking for porcelain-fused-to-metal crowns: a clinical comparison. Int J Periodontics Restorative Dent. 2004 Jun;24(3):22231.

4. Okubo SR, Kanawati A, Richards MW, Childress S. Evaluation of visual and instrument shade matching. J Prosthet Dent. 1998 Dec;80(6):642-8. 
5. Carsten DL. Successful shade matching--what does it take? Compend Contin Educ Dent. 2003;24(3):175-8.

6. Clary JA, Ontiveros JC, Cron SG, Paravina RD. Influence of light source, polarization, education, and training on shade matching quality. J Prosthet Dent. 2016 Jul;116(1):91-7.

7. Gáspárik C, Tofan A, Culic B, Badea M, Dudea D. Influence of light source and clinical experience on shade matching. Clujul Med. 2014;87(1):30-3.

8. Paravina RD, O’Neill PN, Swift EJ Jr, Nathanson D, Goodacre CJ. Teaching of color in predoctoral and postdoctoral dental education in 2009. J Dent. 2010;38 Suppl 2:e34-40.

9. Dozic A, Kharbanda AK, Kamell H, Brand HS. European dental students' opinions about visual and digital tooth colour determination systems. J Dent. 2011 Dec;39 Suppl 3:e23-8.

10. Corcodel N, Karatzogiannis E, Rammelsberg P, Hassel AJ. Evaluation of two different approaches to learning shade matching in dentistry. Acta Odontol Scand. 2012 Jan;70(1):83-8.

11. Hammad IA. Intrarater repeatability of shade selections with two shade guides. J Prosthet Dent. 2003 Jan;89(1):50-3.

12. Draghici R, Preoteasa CT, Tâncu A, Preoteasa E. Dental color assessment through TTB exercises. J Med Life. Jan-Mar 2016;9(1):61-65.

13. Olms C, Klinke T, Pirek P, Hannak WB. Randomized multi-centre study on the effect of training on tooth shade matching. J Dent. 2013 Dec;41(12):1259-63.

14. Llena C, Forner L, Ferrari M, Amengual J, Llambes G, Lozano E. Toothguide Training Box for dental color choice training. J Dent Educ. 2011 Mar;75(3):360-4.

15. Corcodel N, Rammelsberg P, Jakstat H, Moldovan O, Schwarz S, Hassel AJ. The linear shade guide design of Vita 3D-master performs as well as the original design of the Vita 3D-master. J Oral Rehabil. 2010 Nov;37(11):860-5.
16. Borbély J, Varsányi B, Fejérdy P, Hermann P, Jakstat HA. Toothguide Trainer tests with color vision deficiency simulation monitor. J Dent. 2010;38 Suppl 2:e41-9.

17. Udiljak Ž, Illeš D, Knezović Zlatarić D, Ćelić R. Effect of Clinical Experience on the Shade Matching Accuracy in Different Dental Occupational Groups. Acta Stomatol Croat. 2018;52(2):132-139.

18. Pohlen B, Hawlina M, Šober K, Kopač I.Tooth Shade-Matching Ability Between Groups of Students with Different Color Knowledge. Int J Prosthodont. Sep-Oct 2016;29(5):487-92.

19. Ortolan SM, Persic S, Celebic A, Mehulic K. Comparison of time consumption and color matching results of different dental occupational groups. Int J Prosthodont. Sep-Oct 2013;26(5):478-86.

20. Sinmazisik G, Trakyali G, Tarcin B. Evaluating the ability of denta technician students and graduate dentists to match tooth color. J Prosthet Dent. 2014 Dec;112(6):1559-66.

21. Haddad HJ, Jakstat HA, Arnetzl G, Borbely J, Vichi A, Dumfahrt H, Renault P, Corcodel N, Pohlen B, Marada G, de Parga JA, Reshad M, Klinke TU, Hannak WB, Paravina RD. Does gender and experience influence shade matching quality? J Dent. 2009;37 Suppl 1:e40-4.

22. Capa N, Malkondu 0, Kazazoglu E, Calikkocaoglu S. Evaluating factors that affect the shade-matching ability of dentists, dental staff members and laypeople. J Am Dent Assoc. 2010 Jan;141(1):71-6.

23. Ragain JC Jr, Johnston WM. Minimum color differences for discriminating mismatch between composite and tooth color. J Esthet Restor Dent. 2001;13(1):41-8.

24. Xu MM, Xu TK, Liu F, Shi XR, Feng HL. The influence of toothguide training box on shade matching veracity. Shanghai Kou Qiang Yi Xue. 2009 Aug;18(4):432-5.

25. Della Bona A, Barrett AA, Rosa V, Pinzetta C. Visual and instrumental agreement in dental shade selection: three distinct observer populations and shade matching protocols. Dent Mater. 2009 Feb;25(2):276-81. 